Research Article

\title{
D-Shaped Concrete-Filled Steel Tube Structure in Bridge Engineering
}

\author{
Yuan Liu $(1),{ }^{1,2}$ Wei Wang, ${ }^{2}$ Changqing Wang, ${ }^{3}$ Shuosong $\mathrm{Bi}^{2}$ and Jianming $\mathrm{Zhu}^{2}$ \\ ${ }^{1}$ School of Highway, Chang'an University, Xi'an 710064, Shaanxi, China \\ ${ }^{2}$ Beijing Xinqiao Technology Development Co., Ltd., Beijing 100088, China \\ ${ }^{3}$ Shaanxi Provincial Highway Bureau, Xi'an 710068, Shaanxi, China \\ Correspondence should be addressed to Yuan Liu; 2013021023@chd.edu.cn
}

Received 26 November 2020; Revised 22 December 2020; Accepted 23 February 2021; Published 9 March 2021

Academic Editor: Sang-Bing Tsai

Copyright () 2021 Yuan Liu et al. This is an open access article distributed under the Creative Commons Attribution License, which permits unrestricted use, distribution, and reproduction in any medium, provided the original work is properly cited.

With the continuous progress of the construction industry, the requirements for concrete in the bridge engineering are getting higher and higher. This research mainly discusses the detection of D-shaped concrete-filled steel tube structure in bridge engineering. In this study, the $\mathrm{D}$-shaped concrete-filled steel tube member was used as the research object, and the load-displacement curve of the D-shaped concrete-filled steel tube compression-bending member was analyzed by the fiber model program. In the determination of the bonding state of the concrete-filled steel tube interface, in order to avoid the impact of mechanical and manual vibrating and the difference in concrete pouring methods on the test, the study uses C60 self-compacting microexpansion concrete. While pouring the specimens, three sets of cube specimens with a side length of $100 \mathrm{~mm}$ are reserved to determine the mechanical properties of the concrete simultaneously. In the temperature shock measurement of the concrete-filled steel tube specimen, the concrete-filled steel tube specimen was placed in a resistance heater during the simulated heating stage and heated to $20^{\circ} \mathrm{C}, 40^{\circ} \mathrm{C}, 60^{\circ} \mathrm{C}$, and $80^{\circ} \mathrm{C}$ at room temperature. When measuring the mechanical properties of the specimen under the axial load, the specimen is heated from room temperature to the temperature of the entire section to reach $20^{\circ} \mathrm{C}, 40^{\circ} \mathrm{C}, 60^{\circ} \mathrm{C}$, and $80^{\circ} \mathrm{C}$. After preloading, the load of each level is $10 \mathrm{t}$ for continuous operation. Load and record the strain of the steel pipe and concrete under each load. If only the radial effect of the steel tube on concrete is considered, the temperature of $11^{\circ} \mathrm{C}, 20^{\circ} \mathrm{C}$, and $80^{\circ} \mathrm{C}$ is the best ambient temperature. The results show that the D-shaped steel tube concrete interface state can provide a certain theoretical and experimental reference for the optimization of the steel tube concrete interface, ensuring the long-term working performance of the steel tube concrete under the harsh environment.

\section{Introduction}

With the gradual improvement of industry and construction industry, the requirements of mixing concrete in bridge engineering are higher and higher [1]. Under the action of axial pressure, the steel tube is under axial and radial compression, while the circular tension is. The concrete is under three-dimensional compression, and the steel tube and concrete are in three-dimensional stress state. The compressive strength of concrete under three-dimensional compression is greatly improved, while the plasticity is increased, and the concrete material shows good ductility. It is this ductility that determines the basic performance and characteristics of concrete-filled steel tubular (CFST), and as a new type of composite structure, it shows great vitality and development prospects [2].

Due to the complexity of the mechanical properties of steel pipe concrete, the current research level is still lagging behind. In terms of static performance, there are many strength calculation formulas, but due to the inconsistent limit state standards and too many experience coefficients, the calculation results of various formulas are quite different. However, the fiber model analysis method is used to calculate the concrete-filled steel tube component, and the full curve of the force and deformation of the concrete-filled steel tube component can be obtained, and the force 
situation at each stage can be accurately described with high accuracy [3]. In addition, the forms of concrete-filled steel tube members currently studied are mainly round, square, and rectangular.

It is very necessary to experiment and analyze the performance of lightweight concrete steel tube support rods (short columns) under concentric compression. Salgar and Patil used Sintagg (expanded clay aggregate) lightweight aggregate to prepare $40 \mathrm{~N} / \mathrm{mm}$ grade high-strength lightweight concrete. They tested 64 samples to study the axial compression behavior of lightweight concrete-filled tube (LWCFT) braces. They used different strut lengths, cross-sectional dimensions, and thicknesses to enumerate the influence of component geometry and composition material properties on the structural behavior of CFT struts. The ultimate strength results are compared with current codes governing the design of concrete-filled steel tube columns. Their research has too few comparative data [4]. Hayashi et al. studied the seismic performance of a selfcentering swing composite steel/concrete frame system through experiments. The system consists of a doubleskinned concrete-filled steel tube (CFT) column support frame designed as ultra-high-strength (HS) steel to maintain elasticity. Allow the column to be separated from the foundation and the typical all-steel flexural frame (MRF). The fuse is made of conventional steel or low-yieldpoint steel to further improve the deformability. They designed an effective shear transfer mechanism that can effectively achieve the lifting behavior and prevent the column base from slipping. Their research lacks experimental data [5]. Kenarangi and Bruneau research investigated the contribution of steel casing to the structural resistance and seismic response of uniaxial foundations. They studied the composite properties of the specimen and the development of plastic hinges under large deformation and compared the results with the results. Their research method is not perfect [6]. Biswas et al. proposed an innovative beam-column composite node with tight brackets and studied its behavior through finite element analysis. First, they developed two finite element models of boltextended end plate joints in ABAQUS and verified them with available experimental results. Then, based on the modified model, a parameter analysis was performed to evaluate the new joint performance in terms of initial joint stiffness, rotation capacity, torque capacity, failure mode, and joint classification [7]. Their research method is not novel enough [8].

This study takes D-shaped concrete-filled steel tube members as the research object and uses fiber model program to analyze the load-displacement curve of D-shaped concretefilled steel tube compression-bending members. In the determination of the bonding state of the concrete-filled steel tube interface, in order to avoid the influence of mechanical and manual vibrating and the difference of concrete pouring methods on the test [9], the study uses C60 self-compacting microexpansion concrete. While pouring the specimens, three sets of cube specimens with a side length of $100 \mathrm{~mm}$ are reserved to determine the mechanical properties of the concrete simultaneously. In the temperature shock measurement of the concrete-filled steel tube specimen, the concrete-filled steel tube specimen was placed in a resistance heater during the simulated heating phase, and the simulated normal temperature was heated to $20^{\circ} \mathrm{C}, 40^{\circ} \mathrm{C}, 60^{\circ} \mathrm{C}$, and $80^{\circ} \mathrm{C}$.

\section{D-Shaped Steel Tube Concrete}

2.1. Concrete-Filled Steel Tube. Concrete-filled steel tube (CFST) columns are an increasingly popular method of supporting huge compressive loads in buildings $[10,11]$. The remaining strength of the CFST short column can be used to evaluate the potential damage caused by the fire and provide the least structural fire protection for the repair after the fire [12]. Regarding the distribution of CFST arch bridges in industry, they are mainly used in highways and municipal engineering, and their applications in railways, especially in high-speed railways, have grown rapidly $[13,14]$. Among all bridges, $85 \%$ are composed of five types of structural systems, namely: deck bridges, semithrough bridges, combined arch beams, bird arch bridges, and straight-framed arch bridges [15]. For the cross-sectional form of the main arch rib, the popular forms are single tube, dumbbell shape, and truss, with circular steel tube concrete as the basic element $[15,16]$. In various structural systems of CFST arch bridges, especially in long-span railway bridges, basket-shaped arch bridges have been adopted [17]. In the past 20 years, China has made great progress in the construction of concretefilled steel tube arch bridges and concrete arch bridges with CFST skeletons $[18,19]$. The span of these bridges has been increasing rapidly, which is rare in the history of bridge development [20].

2.2. Fiber Model Analysis Method. The analysis of the structure includes two aspects, one is the analysis of the section strength and the other is the analysis of the stability of the component. When the fiber model method is used to study the stable bearing capacity of the component [21], first make an ideal assumption about the deformation of the component during the loading process and then divide the steel pipe into a number of fiber elements of equal area or unequal area on the failure control section and then divide the core concrete into fibers in the same way. After calculating the axial force and bending moment of each unit, the entire section is integrated to obtain the internal force of the section. On the basis of satisfying the balance of internal and external forces, the ultimate stability bearing capacity of the component is finally obtained by the iterative method $[22,23]$. This study first introduced the structural models of steel and concrete used and then explained the calculation principle and calculation process of the fiber model method. Finally, the fiber model method was used to analyze the axial compression performance of the D-shaped steel tube concrete column [7, 24]. For the D-shaped concrete-filled steel tube member of ordinary structure, the cross-section has internal angle, external angle, and the same length-to-width ratio, and there is a big difference in the restraint performance of the core 
concrete between the internal angle and the external angle $[25,26]$.

$$
y=\left\{\begin{array}{l}
2 x-x^{2}, \\
\frac{x}{\beta_{0}(x-1)+x} .
\end{array}\right.
$$

Among them,

$$
\begin{aligned}
x & =\frac{\varepsilon}{\varepsilon_{0}}, \\
f_{\text {co }} & =f_{c}^{\prime}\left[1+\left(-0.0135 \xi^{2}+0.1 \xi\right) \times\left(\frac{24}{f_{c}^{\prime}}\right)^{0.45}\right], \\
\varepsilon_{0} & =\left\{1300+12.5 f_{c}^{\prime}+\left\{1330+760\left[\frac{\left(f_{c}^{\prime}-24\right)}{24}\right] \xi^{0.2}\right\}\right\} \times 10^{-6} .
\end{aligned}
$$

Among them, $f_{c}{ }^{\prime}$ is the compressive strength of the concrete cylinder [27]. When the constraint effect coefficient $\xi$ is the same, but the aspect ratio of the section is different, then

$$
\begin{aligned}
\xi_{B} & =\frac{f_{y} A_{s, B}}{f_{c} A_{c, B}}, \\
\xi_{D} & =\frac{f_{y} A_{s, D}}{f_{c} A_{c, D}}, \\
\xi_{D B} & =\xi_{D}\left(1-\frac{1}{\eta^{2}}\right)+\frac{\xi_{B}}{\eta^{2}} .
\end{aligned}
$$

Among them, $\xi_{D B}$ is the equivalent restraint effect coefficient of the component with the section $D \times B[28,29]$. Based on the concept of weighted average, the equivalent constraint effect coefficient of D-shaped concrete-filled steel tube members can be expressed as follows:

$$
\xi_{\mathrm{eq}}=\frac{\sum_{i} \xi_{i} A_{i}}{\sum_{i} A_{i}}
$$

When the D-shaped concrete-filled steel tube member is in a state of eccentric compression, in addition to the compression zone, there may also be a tension zone in the core concrete. Considering that the tensile strength of concrete is small, the tensile effect of concrete has a greater impact on the bearing capacity of the member. The stressstrain relationship of concrete in the tension zone is as follows:

$$
y=\left\{\begin{array}{l}
1.2 x-0.2 x^{6}, \\
\frac{x}{0.3 f_{t k}^{2}(1-x)^{1.7}+x} .
\end{array}\right.
$$

Among them, $x=\varepsilon / \varepsilon_{t}$.

2.3. Load Path. When the D-shaped concrete-filled steel tube member is under bias, there is an axial force $N$ and a bending moment $M$ in the section of the member. When the mechanical properties are studied, there are different loading paths [13].

(1) First apply the axial pressure $N$, keep the magnitude and direction of the axial pressure $N$ unchanged, and then apply the bending moment $M$ in an equal proportion;

(2) The axial force $N$ and the bending moment $M$ are applied simultaneously in proportion;

(3) First apply the bending moment $M$, keep the magnitude and direction of the bending moment $M$ unchanged, and then apply the axial pressure $N$. Among the three loading methods, the column in the high-rise structure is close to the loading path I under the action of horizontal load. The unidirectional and bidirectional bending members in the engineering structure are loaded according to the loading path II, and the loading path III is in the actual project, and it is relatively rare [30].

Keeping the eccentricity $e$ and the angle $\theta$ constant, the process of applying vertical load to the member is the loading path II. At this time, the vertical pressure $N$ and the two-way bending moment are applied simultaneously in proportion. Different from the loading path I, because the L-shaped section is a uniaxially symmetric section and the concrete material has different tensile and compressive properties, when the load acts on the asymmetric axis ( $X$ axis), the neutral axis of the section during the loading process direction will change and the component will become two-way bending. The fiber model program flow of loading path II is shown in Figure 1, and the preparation steps of the numerical analysis program are as follows.

Suppose $u_{x}$ and $u_{y}$ are, respectively, the maximum deflection in the middle of the span when the component flexes and deforms in the main plane xozand yoz, then

$$
\begin{aligned}
& x=u_{x} \sin \frac{\pi}{l} z, \\
& y=u_{y} \sin \frac{\pi}{l} z .
\end{aligned}
$$

A single enlarged shaft foundation is usually used to support the bridge column. In some cases, it consists of a permanent steel shell, which is usually ignored when calculating the structural resistance of the shaft. The curvature of the midspan section around the $X$ axis and $Y$ axis is as follows: 


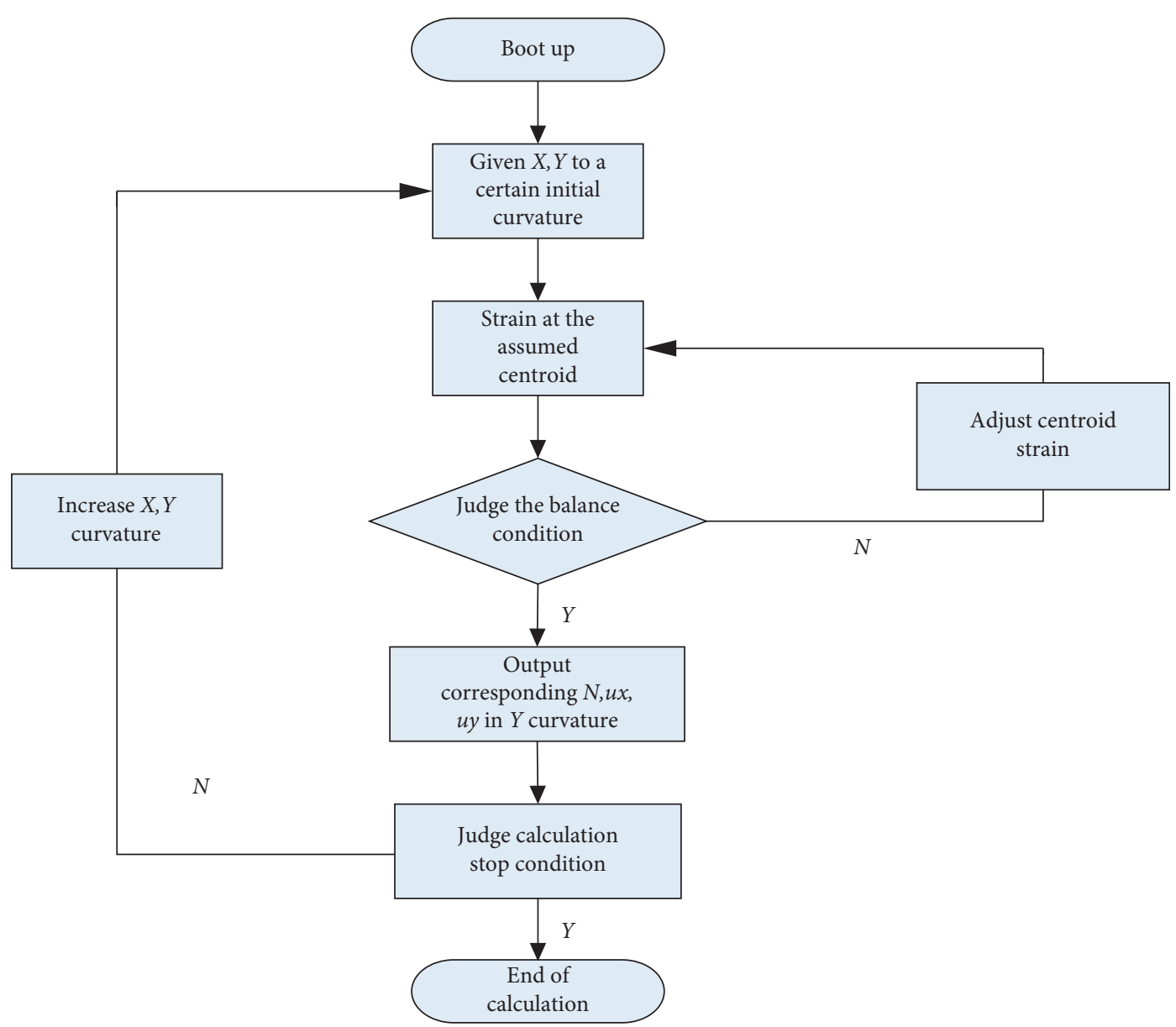

FIgURE 1: The fiber model program flow chart of load path II.

$$
\begin{aligned}
& \varphi_{x}=u_{y} \frac{\pi^{2}}{l^{2}}, \\
& \varphi_{y}=u_{x} \frac{\pi^{2}}{l^{2}} .
\end{aligned}
$$

The strains $\varepsilon_{c j}$ and $\varepsilon_{s j}$ at the centroid of concrete element $j$ and steel tube element $j$ are as follows:

$$
\begin{aligned}
& \varepsilon_{c j}=\varepsilon_{0}+\varphi_{y} x+\varphi_{c j} y_{x}, \\
& \varepsilon_{s j}=\varepsilon_{0}+\varphi_{y} x+\varphi_{s j} y_{x} .
\end{aligned}
$$

From the material constitutive model, the stresses of the concrete element and steel element $j$ are as follows:

$$
\begin{gathered}
\sigma_{c j}=f_{c}\left(\varepsilon_{c j}\right), \\
\sigma_{s j}=f_{s}\left(\varepsilon_{s j}\right) .
\end{gathered}
$$

Then, the bending moment of the component in the two principal axis planes is as follows:

$$
\begin{aligned}
M_{\mathrm{in} x} & =\sum_{j=1}^{k} \sigma_{c j} A_{c j} y_{c j}+\sum_{j=1}^{m} \sigma_{s j} A_{s j} y_{s j}, \\
M_{\mathrm{in} y} & =\sum_{j=1}^{k} \sigma_{c j} A_{c j} x_{c j}+\sum_{j=1}^{m} \sigma_{s j} A_{s j} x_{s j}, \\
N_{\mathrm{in}} & =\sum_{j=1}^{k} \sigma_{c j} A_{c j}+\sum_{j=1}^{m} \sigma_{s j} A_{s j} .
\end{aligned}
$$

Among them, $M_{\mathrm{in} x}$ is the internal bending moment around the $x$-axis, $M_{\text {in } y}$ is the internal bending moment around the $y$-axis, and $N_{\text {in }}$ is the internal force.

\section{Testing Experiment of D-Shaped Steel Tube Concrete Structure}

3.1. Selection of Research Objects. The main factors affecting the bearing capacity of the D-shaped concrete-filled steel tube column structure are the tube wall width-to-thickness 
ratio, the concrete compressive strength, and the steel yield strength. In this study, considering the above main factors, the stability bearing capacity of D-shaped concrete-filled steel tube members with different parameters was analyzed. The values of different parameters are shown in Table 1 . D-Shaped thin-walled round steel pipes were selected for this test. In this test, there are 5 specimens of self-compacting microexpansion concrete short column of the steel tube with exactly the same material and size. Considering that the diameter and thickness of the steel pipe is $21 t \leq D \leq 42 t$ and the length-to-diameter ratio is $L \leq 4 D$, it can represent the actual situation of concrete construction steel pipe concrete, which has a good representativeness. The hoop coefficient $\zeta$ is 0.798 .

3.2. Force Loading of D-Shaped Steel Tube Concrete. This study takes D-shaped concrete-filled steel tube members as the research object and uses fiber model program to analyze the load-displacement curve of D-shaped concrete-filled steel tube compression-bending members. In order to simplify the calculation, the following assumptions are considered:

(1) During the loading process, the cross-section of the component is always kept as a plane, only considering the destruction of the internal and external force balance relationship of the control section and treating it as a zero-length unit

(2) The flexural deformation of the component is halfsine wave

(3) The steel plate and the concrete are completely bonded, and there is no relative slippage between the steel pipe and the concrete

(4) The influence of component shear deformation is not considered

(5) Under pressure and two-way bending moments of the D-shaped concrete-filled steel tube member, in addition to the compression zone, there may also be a tension zone

When the fiber model method is used for numerical analysis of the ordinary structure of the D-shaped concretefilled steel tube compression-bending member, the steel and concrete of the midspan section of the member are divided into a large number of fiber elements, and then the area and coordinates of each fiber element are calculated. The internal force of each fiber through the strain, stress-strain relationship, and area of each fiber element is calculated. Finally, by integrating and summing the internal force of each fiber element, the resultant force of the internal force of the section is obtained, and then according to the balance condition with the internal and external forces, output of the corresponding external loads $N$ and $M$ is found.

\subsection{Bonding State of the Concrete-Filled Steel Tube Interface}

3.3.1. Layout of Measuring Points. The steel pipes are made of Q235 steel, which are all water-cooled and planed on a lathe to avoid the possible impact of temperature stress on the axial compression test of the short column during oxygen welding and strictly guarantee the length, consistency, and processing accuracy. In order to accurately measure the strain and deformation of the specimen under various loads, select $1 / 3,1 / 2$, and $2 / 3$ of the specimen to paste the strain gauges, denoted as 1-1, 2-2, and 3-3 section. Each section has four single longitudinal and hoop strain gauges at $90^{\circ}$ intervals.

3.3.2. Specimen Molding. In order to avoid the impact of mechanical and manual vibrating and the difference in concrete pouring methods on the test and referring to the relevant engineering design standards and construction process requirements, this test uses $\mathrm{C} 60$ self-compacting microexpansion concrete. Among them, the cement model adopts P.0.5-2.5; the coarse aggregate adopts limestone crushed stone with a maximum particle size of $20 \mathrm{~mm}$, which is continuously graded; the fine aggregate adopts standard sand in a dry state; the fly ash uses first-grade fly ash; the superplasticizer uses Vivid-500 multielement carboxylic acid superplasticizer; the expansion agent uses VEA-H concrete expansion agent.

The measured concrete slump on-site is $260 \mathrm{~mm}>250 \mathrm{~mm}$. The expansion degree of concrete is $600 \mathrm{~mm} \geq 600 \mathrm{~mm}$, which meets the design index requirements of self-compacting concrete. While pouring the specimens, three sets of cube specimens with a side length of $100 \mathrm{~mm}$ are reserved to determine the mechanical properties of the concrete simultaneously. When pouring concrete, first erect the steel tube, pour the concrete from the top, and let it stand for 2 hours for curing. The concrete strength is obtained from the test block test formed and cured under the same conditions and finally converted into the strength standard value. In addition, the resistance values of the strain gauges were measured before and after pouring the concrete, and the changes were found to be minimal after comparison [32].

3.4. Temperature Shock Test of Concrete-Filled Steel Tube Specimen. When simulating the heating stage, the concretefilled steel tube specimen was placed in a resistance heater and heated to $20^{\circ} \mathrm{C}, 40^{\circ} \mathrm{C}, 60^{\circ} \mathrm{C}$, and $80^{\circ} \mathrm{C}$ at room temperature. The test piece is heated from room temperature, and the heating ends when the temperature of the concrete at the center of the three sections of the test piece reaches the same level $(T a=T 4 c=T p s)$; in the simulated cooling stage, when the test piece is heated to $80^{\circ} \mathrm{C}$, the resistance heater is turned off and automatically cooled down to normal temperature. From the beginning of heating to each set maximum temperature value and cooling from $80^{\circ} \mathrm{C}$ to normal temperature, the temperature and strain were collected every $15 \mathrm{~min}$.

3.5. Mechanical Properties of Specimens under Axial Load. The main equipment for this test includes ISMN electrohydraulic servo pressure tester, resistance heater, and 
TABLE 1: Values of different parameters.

\begin{tabular}{|c|c|c|c|c|c|c|}
\hline Parameter & $\begin{array}{c}\text { Steel yield } \\
\text { strength }(\mathrm{MPa})\end{array}$ & $\begin{array}{c}\text { Concrete compressive } \\
\text { strength }\end{array}$ & $\begin{array}{l}\text { Tube wall width-to- } \\
\text { thickness ratio (B/t) }\end{array}$ & $\begin{array}{l}\text { Sectional leg width-to- } \\
\text { thickness ratio }\end{array}$ & $\begin{array}{c}\text { Slenderness } \\
\text { ratio }\end{array}$ & $\begin{array}{c}\text { Section } \\
\text { form }\end{array}$ \\
\hline \multirow{3}{*}{ Value } & 235 & C30 & 30 & $(\mathrm{~B} / \mathrm{bl})$ & \multirow{3}{*}{$0-150$} & $\begin{array}{c}\text { L200 } \\
\text { series }\end{array}$ \\
\hline & 345 & $\mathrm{C} 40$ & 37.5 & 2 & & $\begin{array}{l}\text { L250 } \\
\text { series }\end{array}$ \\
\hline & 390 & C60 & 50 & 2.5 & & $\begin{array}{l}\text { L300 } \\
\text { series }\end{array}$ \\
\hline
\end{tabular}

temperature automatic reading recorder. Before the constant temperature loading test of the concrete-filled steel tube specimen, the compressive strength of the concrete standard test block is tested, and its compressive strength is $47.2 \mathrm{MPa}$ and $48.0 \mathrm{MPa}$. The temperature of the specimen is increased from room temperature to the temperature of the entire section to reach $20^{\circ} \mathrm{C}, 40^{\circ} \mathrm{C}, 60^{\circ} \mathrm{C}$, and $80^{\circ} \mathrm{C}$, and then the temperature of the specimen section is constant. After preloading, the load is continuously loaded with each level of $10 t$, and the strain of steel pipe and concrete under each level of load is recorded; until the specimen fails, it is loaded and its ultimate bearing capacity is recorded. The loading device uses a 1500T electro-hydraulic servo pressure testing machine.

\section{D-Shaped Steel Tube Concrete Structure}

4.1. Temperature Influence of Concrete-Filled Steel Tube Specimens. The specimen was heated from room temperature to $20^{\circ} \mathrm{C}, 40^{\circ} \mathrm{C}, 60^{\circ} \mathrm{C}$, and $80^{\circ} \mathrm{C}$, respectively. The temperature change trend of each measuring point of the cross-section during the heating stage with time is shown in Figure 2. The time for the center point of the test piece to reach the set temperature is shown in Table 2. It can be seen from Figure 2 that during the heating stage of the specimen, because the thermal conductivity of concrete is smaller than that of steel pipe, the closer the measurement point is to the center of the section and the thermal conductivity of concrete lags behind that of concrete at other locations, but as the heating time increases, the temperature of each point of the specimen section tends to be similar. Because the heater in this test does not lose heat from the outside world during the heating process of the test piece, under the condition of the output power-fixed and set heating temperature, with the loss of a small amount of heat, the entire section of the test piece is particularly The final heating temperature of the concrete part tends to be similar but not the same; that is, the temperature of the concrete section cannot be the same as the applied temperature set by the heater [33], but it is considered that the temperature of each measuring point of the concrete changes within a certain period of time. It is assumed that its heating has stabilized.

The temperature change trend of each measurement point in the cooling stage with time is shown in Figure 3 [34]. It can be seen from Figure 3 that during the heating and cooling process of the test piece, because the thermal conductivity of concrete is worse than that of steel pipe and the heat storage capacity is better than steel pipe, the heating rate

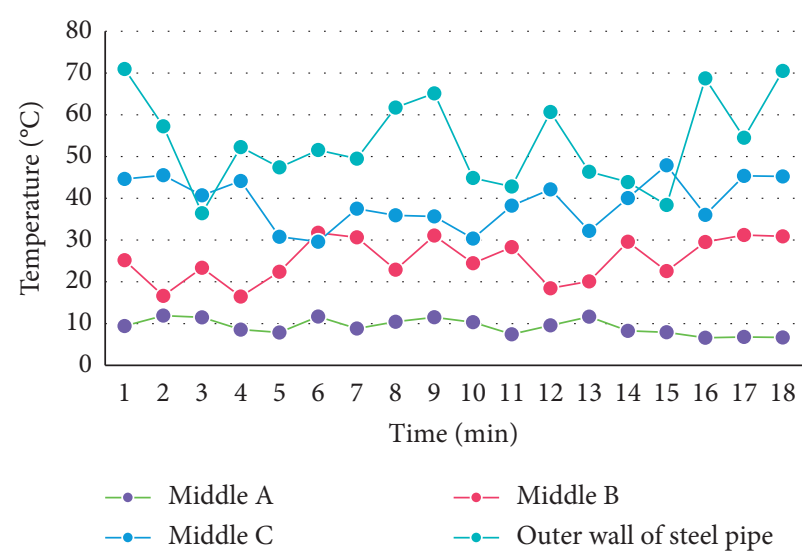

FIgURE 2: The temperature change trend of each measuring point of the cross-section during the heating stage with time.

TABle 2: Time for the center point of the specimen to reach the set temperature.

\begin{tabular}{lllll}
\hline Set test temperature $\left({ }^{\circ} \mathrm{C}\right)$ & 20 & 40 & 60 & 80 \\
\hline Time $(\min )$ & 240 & 120 & 240 & 330 \\
\hline
\end{tabular}

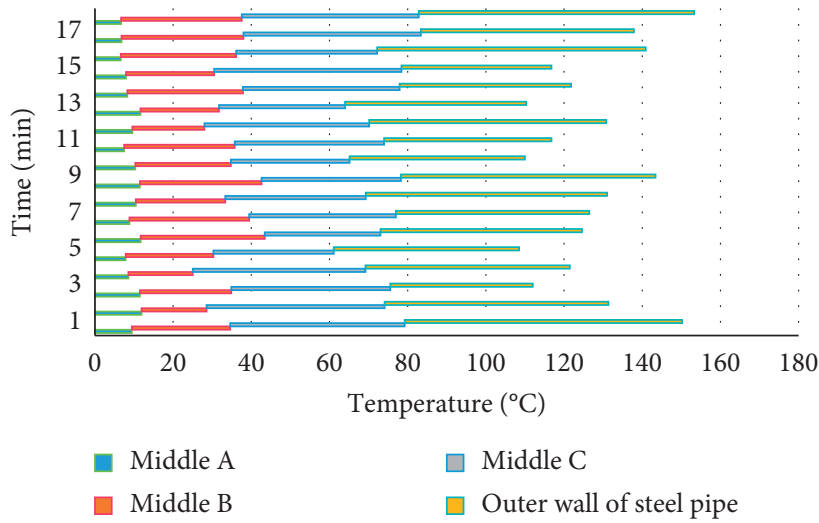

FIGURE 3: The temperature change trend of each measuring point during the cooling stage with time.

of each measuring point from the outside to the inside of the cross-section is gradually reduced during the heating stage and the cooling rate is also gradually reduced during the cooling stage. At $20^{\circ} \mathrm{C}$, because the temperature difference is small, the radial strain changes little, and there are fluctuations in the changes, but the overall trend is to increase first until it stabilizes; at $40^{\circ} \mathrm{C}$, the temperature difference 
becomes slightly larger, and the radial strain changes accordingly there is an increase until it stabilizes; at $60^{\circ} \mathrm{C}$, the temperature difference changes greatly, while the rate of change of radial strain first increases and then decreases [35]. After half of the heating time, the rate of change of radial strain continues to increase until it stabilizes. At $80^{\circ} \mathrm{C}$, the temperature difference change is larger than before, and the radial strain change rate is firstly smaller. After $1 / 3$ of the heating time, the radial strain change rate continues to increase until it stabilizes.

The axial and radial strain changes of D-shaped reinforced concrete at different temperatures are shown in Figure 4 . The change amplitude of radial strain at $20^{\circ} \mathrm{C}$ and $80^{\circ} \mathrm{C}$ is smaller than that at $40^{\circ} \mathrm{C}$ and $60^{\circ} \mathrm{C}$, and the change rate of radial strain at $40^{\circ} \mathrm{C}$ and $60^{\circ} \mathrm{C}$ is faster before it stabilizes; in the first half of the heating process, the amount of strain change over time is relatively large. The hoop strain at $20^{\circ} \mathrm{C}$ and $40^{\circ} \mathrm{C}$ has a smaller amplitude of change than those at $60^{\circ} \mathrm{C}$ and $80^{\circ} \mathrm{C}$, while the hoop strain at $60^{\circ} \mathrm{C}$ and $80^{\circ} \mathrm{C}$ has a larger amplitude and rate of change in the $2 / 3$ time period before the temperature rise. Then, it stabilizes. The hoop strain at $20^{\circ} \mathrm{C}$ and $40^{\circ} \mathrm{C}$ has a smaller amplitude of change than those at $60^{\circ} \mathrm{C}$ and $80^{\circ} \mathrm{C}$, while the hoop strain at $60^{\circ} \mathrm{C}$ and $80^{\circ} \mathrm{C}$ has a larger amplitude and rate of change in the $2 / 3$ time period before the temperature rise. When the heating temperature is $20^{\circ} \mathrm{C}$, the temperature difference is small, and the radial strain change is small, and when the heating temperature is $20^{\circ} \mathrm{C}$ and $40^{\circ} \mathrm{C}$, the hoop strain and axial strain change are small; when the heating temperature is $60^{\circ} \mathrm{C}$, the concrete amplitude and rate of change of radial, hoop, and axial strain are all larger than the related parameters when the temperature rise is 800 . At the same time, a large temperature difference will produce a large temperature strain. Therefore, the temperature difference is large when the temperature rises from normal temperature to $60^{\circ} \mathrm{C}$ and $80^{\circ} \mathrm{C}$. Therefore, the three-directional (radial, circumferential, and axial) strain of the concrete varies greatly.

4.2. Fiber Model Program Verification. In order to verify the correctness of the fiber model used in this research, this section carried out a fiber model numerical analysis on some of the D-shaped concrete-filled steel tube eccentric compression members carried out according to the loading path II. The calculation results of the numerical analysis are shown in Figure 5. The test results are shown in Figure 6. Due to some defects and human negligence in the test process, the test results and the calculation results of the fiber program have a certain deviation. In addition, the curves of the remaining specimens are in good agreement. It can be seen from Figure 6 that the numerical analysis curve and the experimental curve are in good agreement. In general, the numerical analysis curve and the test curve are in good agreement in terms of stiffness at the rising stage, peak load, and decreasing trend of bearing capacity after peak load. Therefore, the fiber model program can better simulate the D-shaped concrete-filled steel tube member. The results show that the $\mathrm{D}$-shaped steel tube concrete interface state

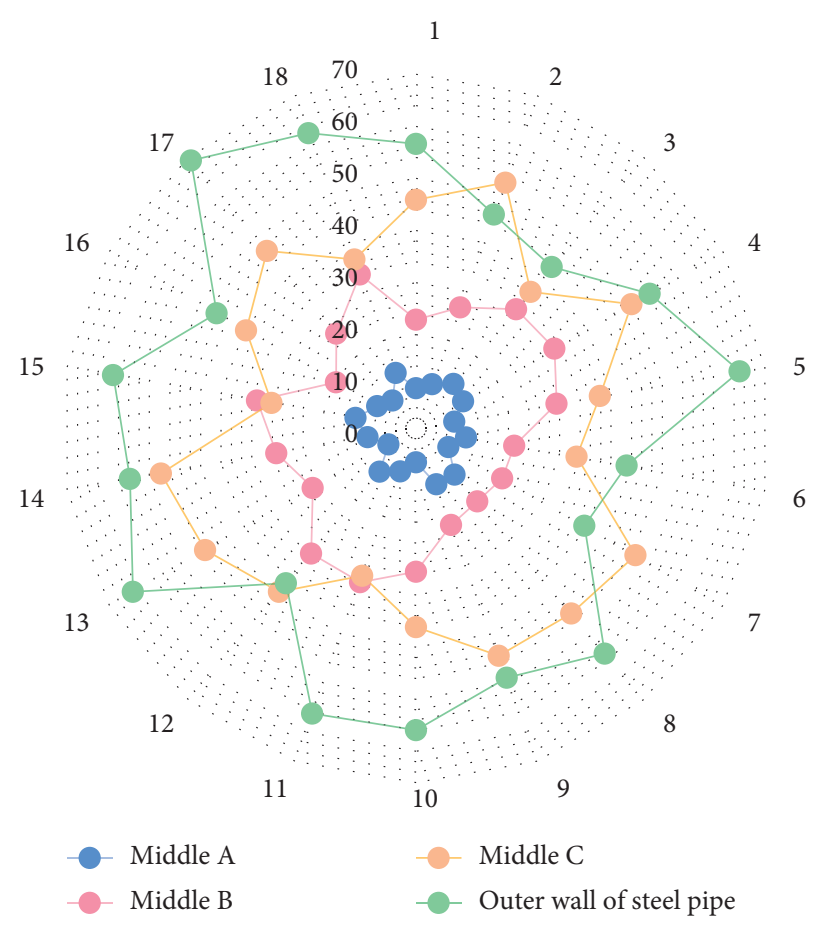

FIGURE 4: The axial and radial strain changes of D-shaped reinforced concrete at different temperatures.

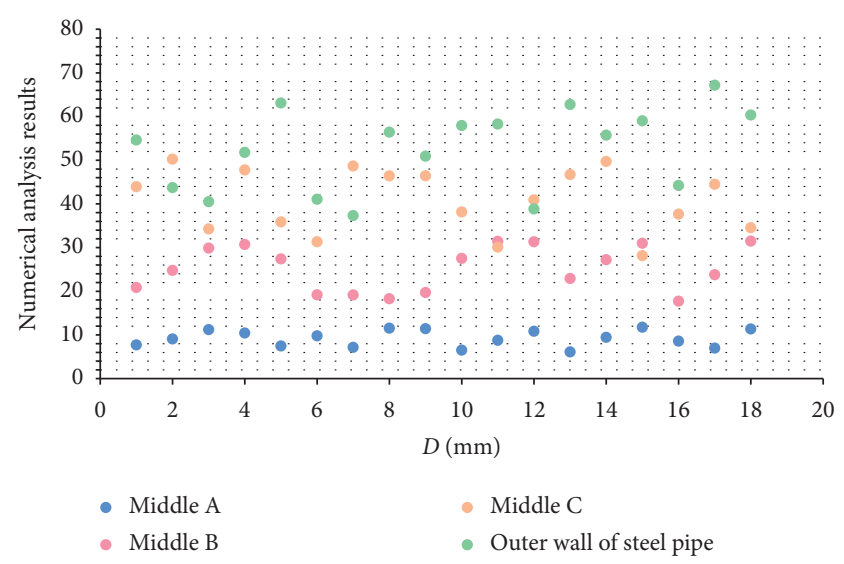

FIGURE 5: Calculation results of numerical analysis.

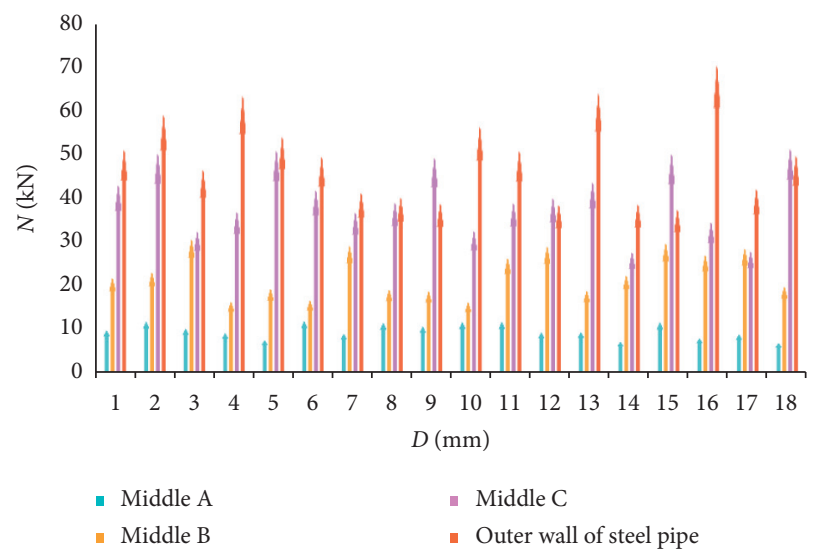

FIGURE 6: Test results. 
can provide a certain theoretical and experimental reference for the optimization of the steel tube concrete interface ensuring the long-term working performance of the steel tube concrete under the harsh environment.

\subsection{Bonding State of D-Shaped Steel Tube Concrete Interface.} The specimens were cured in the curing room for seven days. Before the axial compression test of the test specimens, the concrete strength of three $100 \mathrm{~mm}$ cube concrete specimens cured at the same time and cured under the same conditions were tested. The test results are shown in Table 3. The experimental phenomena at each stage are shown in Table 4. The test phenomena from loading to failure of the five specimens in this test are very similar. In the initial stage of loading, the deformation and morphological changes of the specimen are both. The strain and vertical compressive deformation of the strain gauge section in the specimen basically increase linearly with the increase in the load. With the gradual increase in the load, the surface of the steel pipe is near $120 \mathrm{~T}$. The rust and grout began to peel off, indicating that the steel pipe has yielded, the core concrete inside the steel pipe has a subtle noise, the core concrete has microcracks, and the apparent volume of the steel pipe has increased significantly. As the load continues to increase, when each specimen is near the load range of $136 \mathrm{~T}-144 \mathrm{~T}$, the specimen is damaged in a drum shape, resulting in obvious deformation. The vertical displacement increases sharply, and the failure to continue loading and the excessive vertical compression deformation of the specimen are the criteria for the failure of the specimen, indicating that the specimen has reached the ultimate bearing capacity and is destroyed [36].

The strain gauge data measured before the concretefilled steel tube short column reaches the ultimate bearing capacity are accurate. When the ultimate bearing capacity is approached, the specimen will buckle locally, and the measured data of the strain gauge are very discrete, which causes the strain gauge to fail. In this test, the displacement meter was used to record the displacement under various loads. The mathematical expectation value of the test data is shown in Figure 7. It can be seen from Figure 7 that when the load is in the range of $0-120 \mathrm{~T}$, the strain is in the range of $0-1000 \mu \mathrm{e}$, and when the specimen is in the elastic stage, the axial force-strain curve of each section has a good coincidence. Among them, when the axial load is about $110 \mathrm{~T}$, the strain increases rapidly as the load increases, while the 1-1,33 section, about $120 \mathrm{~T}$, the strain increases faster, which shows that as the axial load increases, The end and middle of the steel pipe are prone to buckling, which is consistent with the experimental phenomenon. When the axial load is $120 \mathrm{~T}$ and the strain is around $1000 \mu \mathrm{e}$, the steel pipe yields. When the load is in the range of $120 \mathrm{~T}$ to $144 \mathrm{~T}$, the specimen enters the elastoplastic stage from the elastic stage. At the same time, it can be seen that the axial strain is about $1000 \mu \mathrm{e}$, while the hoop strain is only about $500 \mu \mathrm{e}$. This shows that at this stage, the axial strain increases faster than the hoop strain, and the hoop strain changes little in the elastic phase. After the load is greater than $144 \mathrm{~T}$, the hoop strain of each section of the steel pipe increases rapidly. The bearing capacity of ordinary concrete-filled steel tube short columns in the elastic stage is only about $60 \%$ of the ultimate load, while the elastic bearing capacity of this test specimen reaches more than $75 \%$ of the ultimate load, which shows that self-compacting microexpansion concrete is beneficial to improve the concrete-filled steel tube short columns. It has elastic bearing capacity, but its elastoplastic stage interval is very small.

4.4. Mechanical Properties of Specimens under Axial Load. The loading temperature and ultimate bearing capacity are shown in Table 5 . It can be seen from Table 5 that the ultimate bearing capacity of concrete-filled steel tube specimens under normal temperature is higher than the ultimate bearing capacity at the set temperature $\left(20^{\circ} \mathrm{C}\right.$ to $\left.80^{\circ} \mathrm{C}\right)$ and increases with the temperature $\left(20^{\circ} \mathrm{C}\right.$ to $\left.80^{\circ} \mathrm{C}\right)$; the ultimate bearing capacity has a decreasing trend. As for the numerical relationship between the decreasing range of bearing capacity and the range of temperature change, the trend and range of the three-dimensional stress change of the interface at different temperatures need to be analyzed. The change of loading temperature and ultimate bearing capacity is shown in Figure 8. The corresponding ambient temperature of $\mathrm{A}, \mathrm{B}$, $\mathrm{C}, \mathrm{D}$, and $\mathrm{E}$ specimens is normal temperature $11^{\circ} \mathrm{C}, 20^{\circ} \mathrm{C}$, $40^{\circ} \mathrm{C}, 60^{\circ} \mathrm{C}$, and $80^{\circ} \mathrm{C}$, as shown in Figure 8. The concretefilled steel tube short column specimens will fail under different temperature and axial compression conditions, and the subsequent failure state is often the end bending. the reason is that it is not crushed. The load-strain curve of the concrete-filled steel tube specimen under axial compression at constant temperature $\left(20^{\circ} \mathrm{C}, 40^{\circ} \mathrm{C}, 60^{\circ} \mathrm{C}\right.$, and $\left.80^{\circ} \mathrm{C}\right)$ is similar to that of the concrete-filled steel tube specimen under normal temperature. Under the conditions of $11^{\circ} \mathrm{C}$, $20^{\circ} \mathrm{C}$, and $80^{\circ} \mathrm{C}$, the change amplitude of the radial strain of concrete is larger than that under the conditions of $40^{\circ} \mathrm{C}$ and $60^{\circ} \mathrm{C}$, while the elastic stage of the load-strain curve at $40^{\circ} \mathrm{C}$ is shorter. The elastic phase of the hoop strain of concrete at $20^{\circ} \mathrm{C}$ and $40^{\circ} \mathrm{C}$ is longer, the hoop strain change at $80^{\circ} \mathrm{C}$ is smaller, and the hoop strain change trend at $11^{\circ} \mathrm{C}$ and $60^{\circ} \mathrm{C}$ is in two cases between. The elastic phase of concrete axial strain is longer at $20^{\circ} \mathrm{C}, 40^{\circ} \mathrm{C}$, and $60^{\circ} \mathrm{C}$, while the change of axial strain at $11^{\circ} \mathrm{C}$ and $80^{\circ} \mathrm{C}$ is smaller. The radial strain of concrete at $40^{\circ} \mathrm{C}$ is smaller, and the axial strain at $80^{\circ} \mathrm{C}$ is smaller. If only considering the restrictive effect of steel pipe on concrete, that is, the radial effect, three temperatures of $11^{\circ} \mathrm{C}, 20^{\circ} \mathrm{C}$, and $80^{\circ} \mathrm{C}$ are the environmental temperatures with the best structural performance.

4.5. Abdominal Force. Under the action of eccentric pressure, the steel pipe has two areas, one is the unit that is subjected to both bending moment and pressure and the other is the unit that only bears the bending moment on the member. In this study, the patch plate is a unit that only bears the bending moment of the member. Due to the structure of the D-shaped member, it is mainly used to resist the bending moment in the $y$-axis with higher bending performance, and the response of the plaque in this case is mainly discussed. According to the calculation results of the 
TABLE 3: Test results.

\begin{tabular}{lccc}
\hline Test block number & Size $(\mathrm{mm})$ & Load $(\mathrm{kN})$ & Test block strength $(\mathrm{MPa})$ \\
\hline $1 \#$ & $100 \times 100 \times 100$ & 507.6 & 50.76 \\
$2 \#$ & $100 \times 100 \times 100$ & 448.4 & 44.8 \\
$3 \#$ & $100 \times 100 \times 100$ & 446 & 44.6 \\
\hline
\end{tabular}

TABLE 4: Test phenomena at various stages.

\begin{tabular}{|c|c|c|c|c|}
\hline \multirow{2}{*}{ Attributes } & \multicolumn{4}{|c|}{ Load } \\
\hline & Early loading & Load to $120 \mathrm{~T}$ & Load to $136 \mathrm{~T}-144 \mathrm{~T}$ & Load to $160 \mathrm{~T}$ \\
\hline Deformation & Has not changed much & Increase evenly & Obviously deformed & Axial displacement increases sharply \\
\hline Phenomenon & No & Drum melody, small sound & Waist drum destruction & Component completely destroyed \\
\hline
\end{tabular}

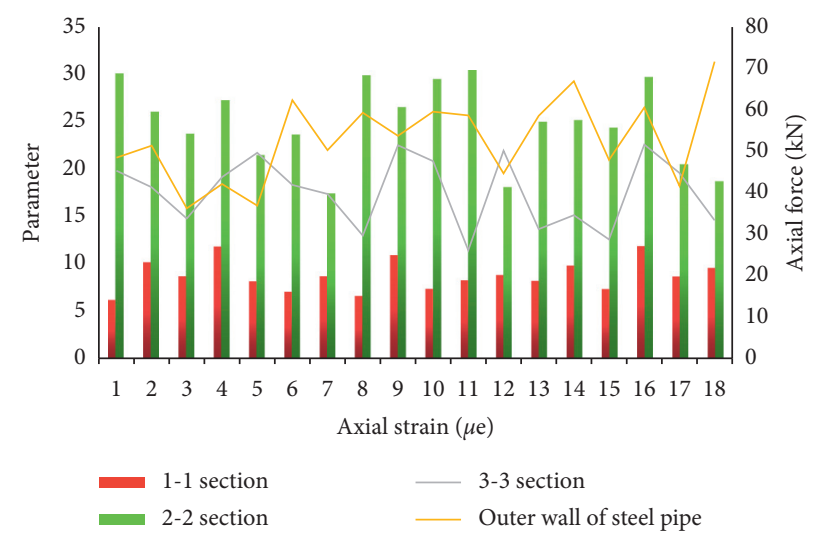

FIgURE 7: Data analysis result of mathematical expectation of experimental data.

TABLE 5: Loading temperature and ultimate bearing capacity.

\begin{tabular}{lcc}
\hline Specimen number & Constant temperature $\left({ }^{\circ} \mathrm{C}\right)$ & Ultimate bearing capacity $(\mathrm{t})$ \\
\hline $\mathrm{A}$ & Room temperature $(11)$ & 190 \\
$\mathrm{~B}$ & 20 & 181.6 \\
$\mathrm{C}$ & 40 & 177.1 \\
$\mathrm{D}$ & 60 & 177 \\
$\mathrm{E}$ & 80 & 171.3 \\
\hline
\end{tabular}

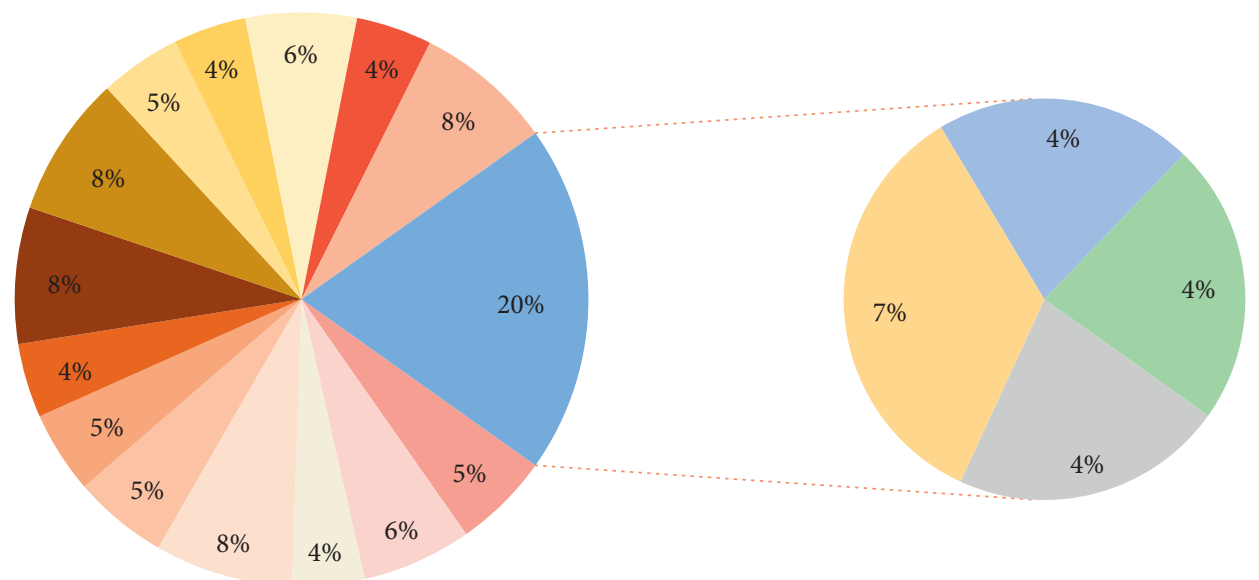
- $20^{\circ} \mathrm{C}$
$60^{\circ} \mathrm{C}$
- $40^{\circ} \mathrm{C}$
$80^{\circ} \mathrm{C}$

FIgURE 8: Changes of loading temperature and ultimate bearing capacity. 
TABLE 6: Stress distribution of plaques and related parts.

\begin{tabular}{lcccccc}
\hline $\begin{array}{l}\text { Eccentric pressure } \\
(\mathrm{kN})\end{array}$ & Plaque & $\begin{array}{c}\text { Intra-abdominal } \\
\text { concrete }\end{array}$ & $\begin{array}{c}\text { Pull zone steel } \\
\text { pipe }\end{array}$ & $\begin{array}{c}\text { Pull zone } \\
\text { concrete }\end{array}$ & $\begin{array}{c}\text { Maximum stress of steel } \\
\text { pipe }\end{array}$ & $\begin{array}{c}\text { Concrete max } \\
\text { stress }\end{array}$ \\
\hline 54 & 41.5 & 1.36 & 23.1 & 1.06 & -119.8 & -14.7 \\
126 & 77.9 & 3.59 & 50.5 & 1.46 & -315.0 & -32.9 \\
\hline
\end{tabular}

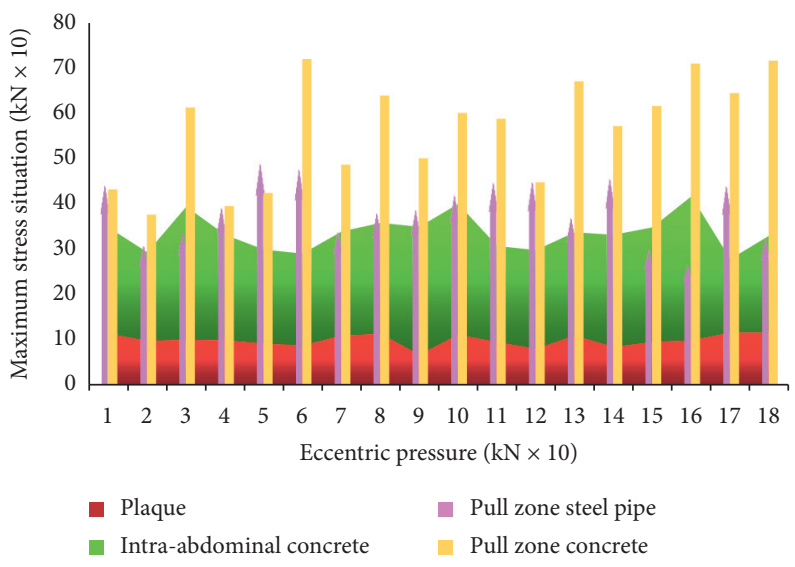

Figure 9: Maximum stress of adjacent steel tube and concrete elements.

program, it is found that there is a certain shear stress in the abdominal cavity, so the tensile stress in a certain direction is relatively large. For steel, the tensile and compressive bearing capacity is the same, while for concrete, the tensile stress is easy to cause the destruction of the unit [37]. The connection between the abdominal cavity and the single round steel tube produces a larger main tensile stress, and the maximum value of the main compressive stress appears at the edge of the compressed round tube far from the neutral axis. The stress distribution of the patch panel and related parts is shown in Table 6. The maximum stress of the adjacent steel tube and concrete element is shown in Figure 9. For comparison, the table also lists the maximum stress value of the steel tube and concrete at this time (where (-) means compression). It can be seen from Table 6 that with the increase in the load, the main tensile stress of the element in the abdominal cavity also increases. Among them, the plaque element has a larger elastic modulus and the load per unit area is also larger. The stress is also larger, and the tensile stress of the concrete unit is lower, but compared with the lower bearing capacity of the concrete itself, $3.68 \mathrm{MPa}$, the tensile stress of the concrete in the abdominal cavity also increases faster. Under the load of (b), tensile stress of concrete even reaches $3.59 \mathrm{MPa}$, and the concrete is about to crack. At this time, the maximum principal compressive stress of the concrete in the nip has reached $329 \mathrm{MPa}$, which is also close to being crushed; at this time, the principal compressive stress of the steel reaches $315.0 \mathrm{MPa}$, which is also very close to its yield load of $353.3 \mathrm{MPa}$. It can be seen that under the bias load of this example, the crushing of the circular pipe part and the tensile failure of the slab concrete proceed simultaneously. Figure 9 also shows the process of the development of concrete from cracks to the final failure of the components. The calculation results of the program also show that after the edge of the steel tube element yields, the adjacent concrete elements are also crushed and unloaded at the same time, and due to the unloading of the concrete, some of the adjacent concrete elements are also crushed, resulting in a larger compression zone. Displacement further increases the displacement difference in the compression zone, so that the tension of the abdominal cavity connected to the two is rapidly expanded, causing the concrete in the abdominal cavity to be damaged, resulting in a decrease in the integrity of the entire structure.

\section{Conclusion}

For the temperature impact test of concrete-filled steel tube specimens, during the simulating heating phase, the concrete-filled steel tube specimens are placed in a resistance heater, and they are, respectively, heated to a gradient temperature from room temperature. The specimen starts to be heated at room temperature and ends when the temperature of the concrete at the center of the three sections of the specimen reaches the same level; in the simulated cooling stage, when the specimen is heated to a certain temperature, the resistance heater is turned off and the temperature is automatically reduced to room temperature. From the beginning of heating to each set maximum temperature and cooling from a certain temperature to normal temperature, the temperature and strain are collected at intervals.

When the fiber model method is used for numerical analysis of the ordinary structure of the D-shaped concretefilled steel tube compression-bending member, the steel and concrete of the midspan section of the member are divided into a large number of fiber elements, and then the area and coordinates of each fiber element are calculated. The internal force of each fiber through the strain, stress-strain 
relationship, and area of each fiber element is calculated. Finally, by integrating and summing the internal force of each fiber element, the resultant force of the internal force of the section is obtained, and then according to the balance condition with the internal and external forces, output of the corresponding external loads $N$ and $M$ is found. The calculation results of the program also show that after the edge of the steel tube element yields, the adjacent concrete elements are also crushed and unloaded at the same time, and due to the unloading of the concrete, some of the adjacent concrete elements are also crushed, resulting in a larger compression zone.

The main equipment for the mechanical performance test of the specimen under the axial load includes the 1SMN electro-hydraulic servo pressure testing machine, resistance heater, and automatic temperature reading recorder. Before the constant temperature loading test of the concrete-filled steel tube specimen, the standard test block of the concrete compressive strength is tested. The temperature of the specimen is increased from room temperature to the temperature of the entire section to reach the gradient temperature, and then the temperature of the section of the specimen is kept constant. After preloading, the load of each level is ten tons for continuous loading, and the steel pipe and concrete under each level of load are recorded. The strain is loaded until the specimen fails, and its ultimate bearing capacity is recorded. The loading device uses an electro-hydraulic servo pressure testing machine.

\section{Data Availability}

No data were used to support this study.

\section{Conflicts of Interest}

The authors declare that they have no conflicts of interest.

\section{References}

[1] A. Raza, Q. U. Z. Khan, and A. Ahmad, "Numerical investigation of load-carrying capacity of GFRP-reinforced rectangular concrete members using CDP model in ABAQUS," Advances In Civil Engineering, vol. 2019, Article ID 1745341, , 2019.

[2] B. Xu, F. Wu, and G. Xu, "Mechanism study on the axial compressive performance of short square CFST columns with different stiffeners," Advances in Civil Engineering, vol. 2018, Article ID 9109371, , 2018.

[3] N. Gao, H. Hou, and J. H. Wu, "A composite and deformable honeycomb acoustic metamaterial," International Journal of Modern Physics B, vol. 32, no. 20, 2018.

[4] P. B. Salgar and P. S. Patil, "Experimental investigation on behavior of high-strength light weight concrete-filled steel tube strut under axial compression," INAE Letters, vol. 4, no. 3, pp. 207-214, 2019.

[5] K. Hayashi, K. A. Skalomenos, H. Inamasu et al., "Self-centering rocking composite frame using double-skin concrete-filled steel tube columns and energy-dissipating fuses in multiple locations," Journal of Structural Engineering, vol. 144, no. 9, pp. 251-263, 2018.
[6] H. Kenarangi and M. Bruneau, "Experimental study on composite action in reinforced concrete-filled steel-tube shaft foundations," Journal of Bridge Engineering, vol. 24, no. 7, pp. 04019060.1-04019060.15, 2019.

[7] S. K. Biswas, D. Devi, and M. Chakraborty, "A hybrid case based reasoning model for classification in internet of things (Iot) environment," Journal of Organizational and End User Computing, vol. 30, no. 4, pp. 104-122, 2018.

[8] S. Chen, J. Jiang, and L. Jia, "Numerical study on the performance of beam-to-concrete-filled steel tube column joint with adapter-bracket," Advances in Structural Engineering, vol. 21, no. 10, pp. 1542-1552, 2018.

[9] X. Sun, H. Zhang, W. Meng, R. Zhang, K. Li, and T. Peng, "Primary resonance analysis and vibration suppression for the harmonically excited nonlinear suspension system using a pair of symmetric viscoelastic buffers," Nonlinear Dynamics, vol. 94, no. 2, pp. 1243-1265, 2018.

[10] H. Luo, W. Wang, W. Wang, G. Wang, and B. Pang, "Study of circular reactive powder concrete-filled steel tube stub columns under axial compression," Journal of Engineering Science and Technology Review, vol. 11, no. 5, pp. 144-152, 2018.

[11] I. A. Alhatmey, T. Ekmekyapar, and S. K. Alrebeh, "Residual strength capacity of fire-exposed circular concrete-filled steel tube stub columns," Advances in Concrete Construction, vol. 6, no. 5, pp. 485-507, 2018.

[12] Y. Wang, H. Chen, and J. Li, "Dynamic characteristics analysis of a curved chord through concrete-filled steel tube truss bridge," World Earthquake Engineering, vol. 33, no. 1, pp. 216-222, 2017.

[13] J. P. Zhang and L. M. Liu, "R\&D and application of curved Dshape concrete-filled steel tube support in roadway support," Geotechnical \& Geological Engineering, vol. 36, no. 6, pp. 1-16, 2017.

[14] B. Chen, J. Wei, J. Zhou et al., "Application of concrete-filled steel tube arch bridges in China: current status and prospects," China Civil Engineering Journal, vol. 50, no. 6, pp. 50-61, 2017.

[15] Q. Feng, Q. Kong, J. Tan et al., "Grouting compactness monitoring of concrete-filled steel tube arch bridge model using piezoceramic-based transducers," Smart Structures \& Systems, vol. 20, no. 2, pp. 175-180, 2017.

[16] T. Ekmekyapar, B. J. M. Al-Eliwi, R. H. Faraj et al., "Performance of lightweight aggregate and self-compacted concrete-filled steel tube columns," Steel \& Composite Structures, vol. 25, no. 3, pp. 299-314, 2017.

[17] J. Dong, H. Ma, Y. Liu, and T. Guo, "Numerical analysis and axial bearing capacity of composite columns with recycled aggregate concrete-filled steel tube and profile steel," Arabian Journal for Science and Engineering, vol. 45, no. 5, pp. 3581-3598, 2020.

[18] V. Horsangchai and A. Lenwari, "Evaluation of AISC 360-16 and eurocode 4 compressive strength equations for concretefilled steel tube columns," Engineering Journal, vol. 24, no. 1, pp. 89-104, 2020.

[19] J. Liu, Z. Li, and F.-X. Ding, "Experimental investigation on the axially loaded performance of notched hexagonal concrete-filled steel tube (CFST) column," Advances in Civil Engineering, vol. 2019, Article ID 2612536, 9 pages, 2019.

[20] D. Gan, Z. Zhou, X. Zhou et al., "Seismic behavior tests of square reinforced concrete-filled steel tube columns connected to RC beam joints," Journal of Structural Engineering, vol. 145, no. 3, pp. 04018267.1-04018267.15, 2019.

[21] R. Pang, B. Xu, Y. Zhou, X. Zhang, and X. Wang, "Fragility analysis of high CFRDs subjected to mainshock-aftershock sequences based on plastic failure," Engineering Structures, vol. 206, Article ID 110152, 2020. 
[22] Q. Shi, W. Cai, and B. Wang, "Axial cyclic testing of concretefilled steel tube columns in diagrid structures," Advances in Civil Engineering, vol. 2019, no. 5, 14 pages, Article ID 4726029, 2019.

[23] Z. Xianggang, W. Shuren, G. Xiang et al., "Seismic behavior analysis of recycled aggregate concrete-filled steel tube column," Journal of Engineering Ence and Technology Review, vol. 12, no. 4, pp. 129-135, 2019.

[24] A. L. Krishan, M. A. Astafeva, and E. P. Chernyshova, "Experimental performance studies of improving compressed concrete filled steel tube elements of square section," IFAC-PapersOnLine, vol. 51, no. 30, pp. 400-404, 2018.

[25] Y. Yong, F. Tao, M. A. Xinbao et al., "Seismic performance of three-directional prestressed columns with a high strength concrete-filled steel tube core: an experimental study," Journal of Harbin Engineering University, vol. 39, no. 3, pp. 461-470, 2018.

[26] J. Ji, Z. Xu, L. Jiang et al., "Nonlinear buckling analysis of H-type honeycombed composite column with rectangular concrete-filled steel tube flanges," International Journal of Steel Structures, vol. 18, no. 4, pp. 1153-1166, 2018.

[27] W. Liang, J. Dong, and Q. Wang, "Axial compressive behavior of concrete-filled steel tube columns with stiffeners," Steel and Composite Structures, vol. 29, no. 2, pp. 151-159, 2018.

[28] R. Shan, X. Zhang, L. Zhang et al., "Application on bearing performance of concrete filled steel tube arch with slip ends," Mtan Xuebao/Journal of the China Coal Society, vol. 43, no. 9, pp. 2461-2468, 2018.

[29] H. Yu, "Tests on the vacuum-aided casting technique for concrete in tubes of concrete-filled steel tube arch bridges and its engineering applications," Structural Engineering International, vol. 28 , no. 1, pp. 28-34, 2018.

[30] J. Zheng and J. Wang, "Concrete-filled steel tube arch bridges in China," Engineering, vol. 4, no. 001, pp. 143-155, 2017.

[31] M. Mao, D. Zhang, Q. Yang, and W. Zhang, "Study of durability of concrete with fly ash as fine aggregate under alternative interactions of freeze-thaw and carbonation," Advances in Civil Engineering, vol. 2019, Article ID 4693893, , 2019.

[32] L. Z. Zhang, M. Mouritsen, and J. R. Miller, "Role of perceived value in acceptance of "bring your own device" policy," Journal of Organizational and End User Computing, vol. 31, no. 2, pp. 65-82, 2019.

[33] I. Kitouni, D. Benmerzoug, and F. Lezzar, "Smart agricultural enterprise system based on integration of internet of things and agent technology," Journal of Organizational and End User Computing, vol. 30, no. 4, pp. 64-82, 2018.

[34] Y. Zhang and P. Huang, "Influence of mine shallow roadway on airflow temperature," Arabian Journal of Geosciences, vol. 13, 2019.

[35] Y. Chen, W. Zheng, W. Li, and Y. Huang, "The robustness and sustainability of port logistics systems for emergency supplies from overseas," Journal of Advanced Transportation, vol. 2020, Article ID 8868533, 2020.

[36] S. Xiao, S. Liu, F. Jiang, M. Song, and S. Cheng, "Nonlinear dynamic response of reciprocating compressor system with rub-impact fault caused by subsidence," Journal of Vibration and Control, vol. 25, no. 11, pp. 1737-1751, 2019.

[37] L. Zeng, G. Chen, and H. Chen, "Comparative study on flowaccelerated corrosion and erosion-corrosion at a $90^{\circ}$ carbon steel bend," Materials, vol. 13, no. 7, p. 1780, 2020. 